Jurnal Interpretasi Hukum |ISSN: 2746-5047

Vol. 2, No. 2 - Agustus 2021, Hal.416-421| Tersedia online di https://www.ejournal.warmadewa.ac.id/index.php/juinhum

DOI : https://doi.org/10.22225/juinhum.2.2.3451.416-421

\title{
TRANSAKSI JUAL BELI MELALUI MEDIA INSTAGRAM MENURUT UNDANG-UNDANG NOMOR 11 TAHUN 2008 TENTANG INFORMASI DAN TRANSAKSI ELETRONIK
}

\author{
I Made Satria Wibawa Tangkeban, I Nyoman Putu Budiartha \& Ni Made Sukaryati Karma \\ Fakultas Hukum Universitas Warmadewa, Denpasar-Bali, Indonesia \\ satriatangkeban01@gmail.com, budiarthaputu59@gmail.com, madesukaryatikarma@gmail.com
}

\begin{abstract}
Abstrak
Internet merupakan media elektronik dan informasi yang perkembangannya sangat cepat. Internet banyak dimanfaatkan dalam berbagai kegiatan yaitu perdagangan, kegiatan perdagangan yang memanfaatkan internet dikenal dengan sebutan e-commerce. Perdagangan di internet itu sendiri menimbulkan banyak permasalahan yang berkaitan dengan hukum dan segala resikonya. Permasalahan yang dapat timbul antara lain adalah wanprestasi. Tujuan penelitian ini adalah untuk menganalisis hak dan kewajiban para pihak dalam transaksi jual beli melalui Instagram dan akibat hukum yang timbul apabila penjual dalam transaksi jual beli melalui Instagram melakukan wanprestasi. Metode penelitian yang digunakan adalah penelitian hukum normatif dengan menggunakan pendekatan perundang-undangan. Sumber bahan hukum primer, sumber bahan hukum sekunder yang dianalisis dengan teknik interpretasi sistematis. Penelitian ini menyimpulkan bahwa: dalam kegiatan jual beli yang dilakukan di Instagram sering terjadi penyimpanganpenyimpangan dalam hak dan kewajiban yang tidak lagi sesuai dengan norma-norma yang ada dalam masyarakat dan upaya hukum yang dapat dilakukan apabila terjadi wanprestasi dari salah satu pihak baik itu penjual dan pembeli yang melakukan transaksi online dapat digugat dalam di dalam lingkungan peradilan umum atau diluar pengadilan dan dapat dikenakan denda secara langsung bagi pihak yang melakukan wanprestasi.
\end{abstract}

Kata Kunci: Internet, Jual Beli, Instagram, Transaksi Elektronik, Wanprestasi.

\begin{abstract}
The internet is an electronic and information medium that is developing very rapidly. The internet is widely used in various activities, namely trade, trading activities that use the internet known as ecommerce. Trading on the internet itself raises many problems related to the law and all its risks. Problems that can arise include default. The research aims are to analyze the rights and obligations of the parties in buying and selling transactions via Instagram and the legal consequences that arise if the seller in the sale and purchase transaction through Instagram defaults. The research method used is normative legal research, with using statutory approach. Primary sources of legal materials, sources of secondary legal materials were analyzed using systematic interpretation techniques. The result shows that in the buying and selling activities carried out on Instagram, there are often deviations in rights and obligations that are no longer in accordance with existing norms in society and legal remedies that can be taken if there is a default from one of the parties, be it the seller. and buyers who make online transactions can be sued within the environment of the general court or outside the court and can be subject to direct fines for parties who do not perform in default.
\end{abstract}

Keywords: Internet, Buying and Selling, Instagram, Electronic Transactions, Default.

\section{PENDAHULUAN}

Perkembangan teknologi di era globalisasi sangatlah pesat, karena teknologi dan informasi di era ini menghadirkan dunia yang lebih luas, tanpa adanya batas jarak, waktu, ruang dan memiliki dampak pada produktivitas dan efisiensi bagi segala kegiatan masyarakat. Penggunaan dari sarana teknologi dan informasi ini telah merubah pola hidup masyarakat, hal tersebut dapat dilihat dari berubahnya tatanan kehidupan masyarakat serta dapat mendorong perubahan kehidupan sosial, ekonomi, budaya dan penegakan hukum. (Siswanto Sunarso, 2009: 39).

Internet merupakan salah satu media informasi dan elektronik yang banyak dimanfaatkan oleh masyarakat dalam berbagai hal, salah satunya adalah perdagangan. Kegiatan perdagangan yang dilakukan dengan internet dikenal dengan istilah e-commerce. Transaksi jual beli secara online di internet dapat diterima dengan baik oleh masyarakat, karena pembeli dapat dengan mudah memilih barang yang diinginkan dengan banyak pilihan di dalamnya dan 
pembeli juga dimudahkan dengan tidak perlu datang langsung ke tempat penjualnya. Facebook, instagram, line, whatsapp, twitter sangat mempengaruhi perkembangan media informasi di Indonesia saat ini, mengingat pengguna sosial media tersebut pada tahun 2020 mencapai 30 juta pengguna. Media sosial yang pada awalnya hanya untuk kebutuhan pribadi dalam membagikan keseharian pengguna, sekarang telah berubah menjadi media yang dapat digunakan dalam perdagangan baik itu berupa barang atau jasa.

Transaksi jual beli dengan media Instagram saat ini memang digemari baik itu dari penjual dan pembeli. Instagram dapat memudahkan penjual dalam menjual atau memamerkan barangnya, karena dalam Instagram dapat mengunggah foto dan disertakan keterangan barang atau jasa yang akan ditawarkan dan hal tersebut dapat mempermudah pembeli dalam memilih dan menentukan pilihannya sesuai dengan foto dan keterangan yang disediakan oleh penjual. Yang melatarbelakangi banyak pembeli melakukan transaksi dengan media Instagram adalah mudahnya akses pembeli dalam mencari barang yang diinginkan, lebih mudah dalam membandingkan harga, pembayaran dapat dilakukan melalui transfer dan menunggu barang datang tanpa harus keluar rumah. Hal-hal tersebutlah yang membuat pembeli tertarik dan lebih efisien waktu karena semua bisa dilakukan dari rumah.

Transaksi jual beli pada umumnya diatur dalam Kitab Undang-Undang Hukum Perdata dalam buku III Tentang Perikatan dan pada Bab 1 dengan Bab V dan beberapa yang berkaitan dengan hukum umum, tetapi secara khusus transaksi jual beli elektronik diatur dalam UndangUndang No 11 Tahun 2008 Tentang informasi dan transaksi elektronik (yang selanjutnya disebut UU No 11 Tahun 2008 Tentang ITE). Undang-Undang No 11 Tahun 2008 Tentang ITE merupakan bagian dari perkembangan KUHPerdata dan bertujuan untuk mengkoordinir kebutuhan masyarakat yang penuh akan teknologi, karena pada transaksi jual beli juga menggunakan internet, sehingga kesepakatan antara pembeli baik berupa barang dan jenis pembayaran ditentukan di internet. (Makarim, 2004:228). Transaksi jual beli dengan media Instagram menawarkan banyak kemudahan baik itu bagi penjual ataupun pembeli. Kemudahan tersebut berupa penawaran dan interaksi yang lebih mudah dilakukan oleh penjual dan pembeli, sehingga memunculkan banyak minat untuk melakukan transaksi dengan Instagram. Instagram memberikan kemudahan bagi penjual dalam menampilkan produk dagangannya beserta keterangan dari produk tersebut dan mempermudah pembeli memilih dan melakukan penawaran serta transaksi.

Banyaknya pengguna dari Instagram menjadikannya digunakan sebagai sarana untuk dijadikan medial jual beli online. Berdasarkan data dari techinasia yang merupakan perusahaan yang bergerak di bidang riset dan analisis asal inggris menyatakan bahwa Indonesia merupakan negara dengan pengguna Instagram terbanyak ketiga di dunia, dengan rentang usia pengguna 89\% berusia 18-34 tahun dan 63\% merupakan perempuan. Dan riset dari TNS juga mengatakan bahwa $45 \%$ dari pengguna Instagram di Indonesia kerap memberi barang-barang yang mereka temui di Instagram. (Fathul Husnan, 2015:4).

Dalam transaksi online akan timbul resiko yang diakibatkan tidak adanya pertemuan selama proses transaksi dan tidak adanya perjanjian jual beli selayaknya transaksi pada umumnya. Hal ini bisa mengakibatkan terjadinya wanprestasi dari salah satu pihak baik itu penjual ataupun pembeli. Wanprestasi itu bisa terjadi karena ada pihak yang tidak memenuhi kewajibannya terhadap pihak lainnya. Terjadinya wanprestasi yang diakibatkan dari transaksi online membuat pemerintah turut berperan dalam mengatasi permasalahan ini. pemerintah menerbitkan pengaturan mengenai transaksi elektronik yang tertuang dalam UU ITE yang didalamnya berisi tentang perlindungan bagi mereka yang melakukan transaksi online dan diharapkan dapat mengurangi potensi penyalahgunaan teknologi dalam melakukan proses perdagangan.

Ada beberapa penelitian terdahulu yang relevan dengan penelitian ini. Menurut Ismoyo (2019) jual beli melalui media instagram telah menciptakan secara langsung hak serta kewajiban kepada kedua belah pihak yaitu konsumen dengan pelaku usaha. Hak dan kewajiban tersebut merupakan kontraprestasi dan prestasi yang harus dilaksanakan dalam hubungan hak dan kewajiban dalam jual beli melalui media instagram. Apabila ada penjual yang melakukan 
wanprestasi penyelesaian dilakukan secara nonlitigasi dengan akibat hukum berupa ganti rugi seperti pengembalian uang, penggantian barang, atau potongan harga barang, dan kompensasi (Septiana \& Fakih, 2018). Tentu hal-hal tersebut merupakan bentuk tanggung jawab yang harus dilakukan oleh pelaku usaha online Instagram. Tak dapat dipungkiri bahwa kegiatan online shop dapat menunjang naiknya suatu brand saat ini (Pratama, 2020). Dalam penelitian Humaira \& Halisa (2021), mereka melihat keefektivan dari pelaksanaan undang-undang Nomor 11 Tahun 2008 Tentang Informasi dan transaksi Elektronik. Dalam penelitian tersebut, dijelaskan bahwa hukum tersebut telah dijalankan sebagaimana mestinya, tetapi dalam pengumpulan bukti membutuhkan waktu yang cukup lama. Dari penjelasan sebelumnya, peneliti memutuskan untuk mengkaji penelitian ini dengan tujuan untuk menganalisis hak dan kewajiban para pihak dalam transaksi jual beli melalui Instagram dan akibat hukum yang timbul apabila penjual dalam transaksi jual beli melalui Instagram melakukan wanprestasi.

\section{METODE PENELITIAN}

Penelitian ini termasuk kedalam penelitian hukum normatif, yang pada dasarnya merupakan penggabungan dari pendekatan hukum normatif dan penambahan unsur serapan di dalamnya. teori hukum kontemplatif yang merupakan gejala umum yang ditimbulkan dari hukum positif yang tujuan nya teoritik dan kebenarannya dianut secara pragmatik yang kegunaannya mengacu pada perbaikan praktik hukum. (Atmadja dan Budiartha, 2018: 48). Teknik pengumpulan bahan hukum yang digunakan adalah: bahan hukum primer yang didapat dengan menganalisis peraturan perundang-undangan, risalah resmi, dan beberapa keputusan-keputusan yang menyangkut dengan judul tulisan ini. bahan hukum sekunder didapat dari menganalisis bukubuku, jurnal-jurnal dan hasil-hasil penelitian terdahulu yang memiliki keterkaitan dengan judul penulisan ini. Dan bahan hukum tersier yang dapat menunjang bahan hukum primer dan sekunder seperti kamus-kamus hukum dan tulisan yang dapat diakses melalui internet. Bahanbahan yang telah didapat kemudian dianalisis menggunakan teknik deskripsi, yang dimana teknik ini memaparkan isu hukum dengan menguraikan secara rinci bahan-bahan yang telah disediakan, yang kemudian ditafsirkan dengan sistematis dan gramatika. Yaitu penafsiran yang menitikberatkan pada kaitan pengaturan hukum yang satu dengan yang lainnya serta mencari artikel yang memiliki substansi yang sama dengan tema penulisan dan menggunakan bahasa hukum hukum.

\section{HASIL PENELITIAN DAN PEMBAHASAN \\ 1. Pengaturan Hak dan Kewajiban Antara Para Pihak Dalam Transaksi Jual Beli Melalui Instagram}

Yang melatarbelakangi banyak pembeli melakukan transaksi dengan media Instagram adalah mudahnya akses pembeli dalam mencari barang yang diinginkan, lebih mudah dalam membandingkan harga, pembayaran dapat dilakukan melalui transfer dan menunggu barang datang tanpa harus keluar rumah. Hal-hal tersebutlah yang membuat pembeli tertarik dan lebih efisien waktu karena semua bisa dilakukan dari rumah. Transaksi jual beli pada umumnya diatur dalam Kitab Undang-Undang Hukum Perdata dalam buku III Tentang Perikatan dan pada Bab 1 dengan $\mathrm{Bab} \mathrm{V}$ dan beberapa yang berkaitan dengan hukum umum, tetapi secara khusus transaksi jual beli elektronik diatur dalam Undang-Undang No 11 Tahun 2008 Tentang informasi dan transaksi elektronik (yang selanjutnya disebut UU No 11 Tahun 2008 Tentang ITE).

Dalam Undang-Undang Hukum Perdata banyak memuat tentang macam bentuk perjanjian jual beli yang diantaranya adalah: perjanjian jual beli dengan percobaan, perjanjian jual beli dengan contoh, penjualan barang milik orang lain dan perjanjian jual beli secara kredit. (Pikahulan, 2008:59). Dalam Undang-Undang perlindungan konsumen didalamnya telah mengatur tentang empat dasar hak dari konsumen. Hak konsumen untuk mendapatkan lingkungan transaksi yang sehat, tidak dimasukkan ke dalam UUPK yang mana hanya secara khusus mengecualikan hak-hak atas kekayaaan intelektual di bidang lingkungan pengelolaan. Hak-hak dari konsumen sebagaimana telah diatur dalam pasal 4 UU No. 8 Tahun 1999 adalah 
sebagai berikut: ha katas keselamatan dan kenyamanan yang diakibatkan dari konsumsi dan pemakaian barang, hak untuk memilih dan mendapatkan barang sesuai dengan apa yang sudah dipilih, ha katas informasi atas barang, hak mendapatkan advokasi dalam perlindungan hukum apabila barang tersebut merugikan, hak untuk mendapatkan pendidikan konsumen, hak atas pelayanan yang ramah dari pihak produsen, hak atas ganti rugi apabila barang yang diterima konsumen tidak sesuai dengan permintaan dan beberapa hak yang telah diatur dalam peraturan perundang-undangan lainnya. (Zulham, 2013:67).

Selain hak-hak atas konsumen, terdapat juga hak-hak yang dilindungi akibat dari adanya persaingan usaha yang tidak sehat. Hak-hak atas perlindungan dari persaingan usaha tidak sehat ini muncul karena dalam kegiatan bisnis sering terjadi upaya kecurangan baik itu yang bisa merugikan sesama pengusaha atau merugikan konsumen. Perlindungan hak-hak konsumen muncul karena banyaknya perilaku curang yang dilakukan oleh pihak pelaku usaha, karena hal tersebutlah banyaknya tuntutan akan perlindungan hak untuk konsumen itu sendiri.

Tidak hanya konsumen, pelaku usaha juga memiliki hak-hak seperti yang tertuang dalam UU No. 8 Tahun 1999 yang menyatakan sebagai berikut: hak untuk menerima pembayaran dari barang yang telah dibeli konsumen, hak untuk mendapat perlindungan atas tindakan yang dilakukan konsumen, hak melakukan pembelaan apabila terjadi permasalahan dengan konsumen, hak atas pemulihan nama baik apabila telah terbukti tidak merugikan konsumen. Jika diperhatikan hak dan kewajiban dari pelaku usaha dan konsumen sangat jelas ada timbal balik di dalamnya. Yang berarti hak bagi konsumen merupakan kewajiban bagi pelaku usaha dalam pemenuhannya sedangkan hak bagi pelaku usaha merupakan kewajiban bagi konsumen dalam pemenuhannya. Negara telah mengatur tentang kewajiban yang harus dipenuhi oleh pelaku usaha sesuai dengan pasal 7 UU No. 8 Tahun 1999 yang menyatakan: beritikad baik dalam melakukan usaha, memberikan informasi yang benar dan jujur atas produk atau jasa yang ditawarkan, melakukan pelayanan dengan konsumen, menjamin mutu dari barang atau jasa yang pelaku usaha tawarkan, memberikan kesempatan bagi konsumen untuk menguji ketahanan dari barang atau jasa yang ditawarkan, memberikan kompensasi atau penggantian atas barang yang dapat mengakibatkan kerugian bagi konsumen selama pemakaiannya.

\section{Akibat Hukum Yang Timbul Apabila Penjual Dalam Transaksi Jual Beli Melalui Instagram Melakukan Wanprestasi}

Yang di maksud dengan prestasi adalah perikatan yang bertujuan untuk memberikan sesuatu, menjalankan sesuatu, menerima sesuatu, berbuat sesuatu atau tidak berbuat sesuatu, sesuai dengan yang dijelaskan didalam pasal 1234 KUHPerdata. Prestasi juga dapat diartikan sebagai isi yang tertuang didalam sebuah perjanjian yang didalamnya berisi hak dan kewajiban yang harus dipenuhi oleh kedua belah pihak yang telah menyepakati perjanjian tersebut. Wanprestasi yang dilakukan oleh debitur dapat berupa empat hal berikut, yaitu: tidak melakukan apa yang telah disanggupi dalam kesepakatan awal, melaksana kan apa yang dijanjikan tetapi tidak sesuai dengan apa yang dijanjikan, terlambat dalam menyelesaikan apa yang dijanjikan melakukan sesuatu yang tidak boleh dilakukan sesuai dengan perjanjian. (Patrik, 1994: 11).

Wanpretasi dapat terjadi karena adanya kesalahan, kelalaian dan kesengajaan. Debitur itu sendiri memiliki kewajiban menyerahkan barang, tidak memiliki kewajiban dalam melakukan perawatan barang seperti yang sudah diisyaratkan oleh Undang-Undang dan tidak bertanggung jawab atas berkurangnya nilai harga dari barang tersebut. Kesengajaan adalah perbuatan yang dilakukan oleh seseorang dengan kesadaran dan dikehendaki. Terjadinya kesengajaan tidak diperlukan adanya tujuan untuk menimbulkan kerugian terhadap orang lain, melainkan cukup diketahui oleh pelaku. Sedangkan kelalaian adalah kegiatan yang dilakukan dan pelaku telah mengetahui akibat yang akan timbul dari tindakan yang dilakukannya.

Wanprestasi yang terjadi dalam suatu perjanjian bertujuan untuk tidak melakukan suatu perbuatan. Apabila orang tersebut tidak melakukan pemenuhan hak yang seharusnya dilakukannya maka orang tersebut dapat dikatakan melakukan wanprestasi. Terjadinya wanprestasi dapat menimbulkan akibat atau gantu rugi yang akan ditimbulkan bagi pihak yang merugikan dan akan ditujukan bagi pihak yang dirugikan. Akibat yang dapat ditimbulkan jika 
terjadi wanprestasi yaitu: membayar kerugian materiil yang dialami oleh kreditur, pembatalan atas perjanjian yang telah disepakati sebelumnya, peralihan resiko yang bisa dialihkan ke debitur, membayar biaya perkara apabila perkara wanprestasi diperkarakan lewat jalur hukum atau pengadilan. Wanprestasi dapat terjadi apabila debitur telah dinyatakan lalai dalam upaya pemenuhan hak kreditur. Atas dasar tersebut lah debitur dapat dinyatakan melakukan kesalahan, kesengajaan atau kelalaian dalam upaya pemenuhan hak dari kreditur dan pihak kreditur dapat melakukan somasi atas kelalaian yang dilakukan oleh debitur serta debitur dapat dinyatakan telah melakukan wanprestasi. Dengan dilakukannya wanprestasi oleh salah satu pihak, maka pihak yang merasa dirugikan atau merasa haknya tidak dipenuhi sesuai dengan perjanjian awal oleh pihak lainnya, maka pihak yang dirugikan dapat melakukan gugatan dalam upaya untuk menegakkan hak-haknya yang seharusnya dipenuhi oleh pihak lainnya.sesuai dengan yang telah tertuang dalam kontrak.

Hak-hak atas gugatan dapat diajukan secara tersendiri ataupun dikombinasikan dengan gugatan lain, yang meliputi: gugatan atas dasar pemenuhan hak, ganti rugi kerugian yang ditimbulkan akibat wanprestasi, pembubaran atau pembatalan terhadap kontrak, pemenuhan hak serta ganti rugi atas kerugian yang ditimbulkan dan pembubaran yang ditambah dengan ganti rugi pelengkap atas kerugian. Penyelesaian sengketa wanprestasi dapat dilakukan dengan upaya non litigasi, dimana upaya penyelesaiaan sengketa ini dilakukan dengan tujuan pemenuhan hak bagi pihak yang dirugikan oleh pihak yang merugikan secara mediasi dan atas kesepakatan yang diambil bersama dalam proses mediasi. Tetapi apabila proses mediasi ini tidak mencapai kesepakatan, maka dapat dilakukan tuntutan ke pengadilan. Penyelesaian melalui pengadilan umumnya membutuhkan waktu yang lama dan biaya perkara yang cukup besar, sehingga penyelesaiannya dalam pengadilan tidak menjadi pilihan utama bagi penyelesain permasalahan wanprestasi. Mediasi menjadi pilihan utama dalam menyelesaikan masalah wanprestasi karena waktu penyelesain dianggap lebih singkat dan biaya yang dikeluarkan dalam penyelesaian perkara dirasa lebih ringan. Pengaturan mengenai transaksi jual beli telah diatur dengan baik di dalam UU No. 11 Tahun 2008 dan juga telah dilaksanakan dengan baik. Perlindungan hak dan kewajiban baik itu konsumen dan pelaku usaha telah diatur dengan sedemikian rupa dalam UU No. 8 Tahun 1999, sehingga menimbulkan rasa aman bagi konsumen dalam melakukan transaksi jual beli dan memberikan rasa aman bagi produsen dalam memasarkan produknya.

\section{SIMPULAN DAN SARAN}

\section{Simpulan}

Dari penjelasan pembahasan di atas dapat disimpulkan bahwa, hak dan kewajiban dalam transaksi atau jual beli online adalah, pembeli menerima barang sesuai dengan yang dipesan dan penjual menerima pembayaran sesuai dengan yang telah ditawarkan. Penjual dan pembeli berhak atas rasa aman dan nyaman dalam melakukan transaksi atau jual beli online tanpa mengalami intervensi atau tekanan dari salah satu pihak. Ketentuan mengenai terpenuhi atau tidaknya hak dan kewajiban dari pembeli dan penjual tertera dalam KUHPerdata dan UU Perlindungan Konsumen. Dalam jual beli online kerap kali terjadi penyimpangan hak dan kewajiban yang dilakukan oleh salah satu pihak, yang seharusnya dimana pihak penjual harus melakukan pemenuhan barang sesuai dengan yang ditawarkan dan dibeli oleh pembeli, serta pihak pembeli harus melakukan pembayaran sesuai dengan harga barang yang telah dibeli. Dan dapat disimpulkan bahwa, akibat hukum yang dapat ditimbulkan dari wanprestasi terhadapa kegiatan jual beli di media Instagram memiliki dua kemungkinan, yaitu: pihak yang melakukan wanprestasi diharuskan memenuhi tuntutan dari pihak yang merasa telah dirugikan sesuai dengan ketentuan dalam Pasal 1267 KUHPerdata dan apabila pemenuhan atas tuntutan tersebut tidak dipenuhi, maka perkawa wanprestasi ini dapat di bawa ke pengadilan dan biaya atas perkara dilimpahkan ke pihak yang melakukan wanprestasi.

\section{Saran}

Melalui kajian ini penulis ingin menyampaikan beberapa saran yang dapat membuat bisnis online lebih baik kedepannya. Untuk melindungi pihak yang melakukan transaksi jual beli 
online diperlukan adanya pendaftaran terkait bisnis online tersebut. Serta perlunya ada UndangUndang yang mengatur secara jelas dan tegas mengenai jual beli online. Dan masyarakat juga harus lebih selektif dalam melakukan transaksi jual beli online dengan mengedepankan aspek keamanan dan transaksi, kehati-hatian sebagai pertimbangan utama dalam melakukan transaksi. Hendaknya, apabila terjadi wanprestasi dalam jual beli online, para pelaku usaha dapat melakukan upaya non litigasi dalam penyelesaiannya, baik itu dengan tujuan dapat dilakukan kompromi, mediasi dan negosiasi atas pemenuhan hak dari pihak yang merasa dirugikan dan dilaksanakan dengan itikad baik dari kedua belah pihak.

\section{DAFTAR BACAAN}

Atmadja, I. D. G., \& Budiartha, I. N. P. (2018). Teori-Teori Hukum. PT. Citra Intrans Selaras, Malang.

Humaira, \& Halisa, F. (2021). Efektivitas Pelaksanaan Undang-Undang Nomor 11 Tahun 2008 Tentang Informasi Dan Transaksi Elektronik Khusus Pasal 28 Ayat (1) Jo. UndangUndang Nomor 19 Tahun 2016 Pasal 45a Ayat (1) Terhadap Penanggulangan Tindak Pidana Penipuan Online Melalui Media Sosial. Fakultas Hukum, Universitas Islam Kalimantan.

Ismoyo, I. S. (2019). Transaksi Jual Beli Melalui Media Instagram Menurut Undang-Undang Nomor 11 Tahun 2008 Tentang Informasi Dan Transaksi Elektronik. Fakultas Hukum, UNISULA.

Makarim, E. (2004). Kompilasi hukum telematika. Raja Grafindo Persada, Jakarta.

Patrik, P. (1994). Dasar-Dasar Hukum Perikatan. Kencana. Jakarta.

Pikahulan, R. M. (2008). Hukum Perikatan. Surya Abadi, Jakarta.

Pratama, Y. (2020). Tanggung Jawab Pelaku Usaha Terhadap Kerugian Konsumen Atas Pemanfaatan Instagram Dalam Transaksi Online Dihubungkan Dengan Undang-Undang Nomor 8 Tahun 1999 Tentang Perlindungan Konsumen Jo. Undang Undang Nomor 19 Tahun 2016 Tentang Perubahan Atas Undang-Undang Nomor 11 Tahun 2008 Tentang Informasi dan Transaksi Eletronik. Fakultas Hukum, Universitas Pasundan.

Septiana, D., \& Fakih, M. (2018). Transaksi Jual Beli Melalui Media Instagram Menurut Undang-Undang Nomor 11 Tahun 2008 Tentang Informasi Dan Transaksi Elektronik. Pactum Law Journal, Vol.1(2).

Sunarso, S. (2009). Hukum Informasi dan Transaksi Elektronik. Rineka Cipta, Jakarta.

Zulham. (2013). Hukum Perlindungan Konsumen. Kencana Prenada Media, Jakarta. 